http://dx.doi.org/10.12775/szhf.2016.055

PAWę RzeWUSKI

Uniwersytet Warszawski, Warszawa, Polska

GENZYP@GMAIL.COM

\title{
Sarmaci, niewolnicy Maryi (wprowadzenie do tekstu Jana Chomentowskiego Pętko Panny Maryjej albo sposób oddawania się Błogosławionej Pannie Marii za sługe i niewolnika)
}

\section{Mancipium Mariae}

Niewolnictwo mariańskie - Mancipium Mariae - należy do grona zapomnianych dzisiaj praktyk religijnych. Po rozkwicie w Zachodniej Europie na przełomie wieków XII i XIII swój renesans przeżyło na przełomie wieku XVI i XVII. Jego podstawowym założeniem jest dążenie do zbawienia poprzez ascezę, polegającą na wyrzeczeniu się wolności i poddaniu się pod władzę Maryi, będącej władczynią świata.

Autorem, którego uznaje się za inspiratora niewolnictwa mariańskiego jest żyjący w XI wieku benedyktyn Piotr Damiani ${ }^{1}$. Początkowo była to forma duchowości obecna przede wszystkim w murach klasztornych. Kult w masowej formie rozwinął się dopiero na przełomie wieków XVI i XVII, kiedy ideę

1 J. Pach, Rola Najświętszej Matki w duchowości europejskiej XVII w., [w:] Królowa Korony Polskiej. Od ślubów króla Jana Kazimierza do kardynała Stefana Wyszyńskiego, Jasna GóraWarszawa 2006, s. 91. 
obecną w zakonach franciszkanów, benedyktynów i cystersów przejęli również jezuici. W czasach kontrreformacji rozpalenie na nowo wiary w dziesiątkach wiernych i przedstawienie im stosunkowo nowej (w rozumieniu nieznanej) formy duchowości wydaje się dalekowzrocznym posunięciem. Poprzez wpisaną w nią zasadę podległości znacznie łatwiej było przekonać do akceptacji przeżywającej kryzys władzy papieskiej.

Jezuici zaczęli propagować kult Maryi w Hiszpanii, Francji oraz Polsce. Jej ojczyzną był jednak Półwysep Iberyjski. W królestwie Hiszpanii w 1606 roku powstało „Arcybractwo Niewolników Najświętszego Sakramentu i Matki Bożej Wygnanej”2. Jego fundatorem był benedyktyn Antonii de Alvardo. Popularność wśród franciszkanek zyskały natomiast za sprawą Agnieszki Rodrigo $^{3}$. W Hiszpanii powstał również jeden $\mathrm{z}$ najważniejszych tekstów tego nurtu O doskonałym nabożeństwie do Najświętszej Maryi Panny św. Ludwiki Grigon de Montfort. W tekście nie tylko wskazano Hiszpanię jako ojczyznę niewolnictwa mariańskiego, ale również wspomniano o Polsce jako o kraju, w którym także rozwija się kult maryjny ${ }^{4}$.

W Rzeczypospolitej pierwszy akt oddania się Maryi w niewolę datuje się na rok $1582^{5}$. Niemniej zwiększenie popularności kultu niewolnictwa mariańskiego było możliwe dzięki wizycie na dworze belgijskim królewicza Władysława Wazy, gdzie zapoznał się on z dziełem Phoenix Thenesis Redivius ojca Bartłomieja de los Rois 6 . Owocem fascynacji nowym nurtem było napisane przez jezuitów w 1623 roku Mariae mancipium.

$$
\text { Pętko Panny Maryjej - } 1632
$$

Prekursorem i inspiratorem pierwszego polskiego dzieła poświęconego niewolnictwu mariańskiemu był Kacper Drużbicki - jezuita mistyk-asceta, autor licznych nabożeństw oraz propagator kultu Serca Chrystusa ${ }^{7}$. W swo-

2 E. Reczek, Wstęp, [w:] Niewolnictwo Mariańskie. Dwie Publikacje Polskich Jezuitów z roku 1632, oprac. E. Reczek, Rzym 1964, s. 9.

3 Tamże, s. 11.

4 J. Pach, Rola Najświętszej Matki..., s. 90.

5 K. Górski Od religijności do mistyki, Lublin 1962, s. 131 (autor podaje za rękopisem o. S. Szafrańca, Śluby Jana Kazimierza, maszynopis na Jasne Górze, s. 95-98).

${ }^{6}$ E. Reczek, Wstęp, s. 14.

7 Encyklopedia wiedzy o jezuitach na ziemiach Polski i Litwy, 1564-1995, red. L. Grzebień i in., Wydział Filozoficzny Towarzystwa Jezusowego, Kraków 1996, s. 133. 
ich pismach przedstawiał możliwość oddania się w niewolę Maryi, jednak nigdzie nie rozwinął tej myśli. Podjęli się tego jego uczniowie.

Mariae mancipium / Pętko Panny Maryjej albo sposób oddawania się Błogosławionej Pannie Marii za sługę i niewolnika należy intepretować nie tylko jako tekst religijny, ale jako pismo filozoficzne, przedstawiające pewną bardzo konkretną wizję świata, stojącą w opozycji do rozwiniętego już w tym czasie sarmatyzmu - mającego swój wyraz w złotej wolności i jak największej emancypacji. Tekst stał się zarazem początkiem dla nowej formy kultu w Polsce ${ }^{8}$.

Autorami podwójnego dzieła było dwóch jezuitów. Pierwszy z nich Franciszek Stanisław Fenicki, wykształcony w filozofii i retoryce, który już jako dojrzały człowiek wstąpił do zakonu, gdzie ukończył studia teologiczne. Następnie zajmował się nauczaniem młodzieży w Sodalicji Mariańskiej. Podczas pracy z młodymi ludźmi propagował między innymi kult niewolnictwa mariańskiego. Polskim przekładem tekstu zajął się jego współbrat zakonny Jan Chomontowski, rektor kolegium lubelskiego oraz tłumacz niemieckich ascetyków ${ }^{9}$.

Na to, że Pętko Panny Maryjej było nie tylko tekstem religijnym, ale również pewnym projektem modelu społecznego wskazują co najmniej dwie rzeczy. Dowodzi tego porównanie z innymi pismami religijno-społecznymi oraz analiza struktura Pętka. Zrozumienie nie tylko religijnego, ale i filozoficznego aspektu tekstu Pętka Maryjnego wymaga przedstawienia go na tle duchowości i religijności epoki.

Znane są liczne pisma jezuitów, których celem było zmienienie nastawienia szlachty w stosunku do chłopów. W swoich kazaniach przeciwko zmuszaniu do niewolniczej pracy chłopów opowiadali się Piotr Skarga, Fabian Birkowski, Jakub Olszewski, Mateusz Bembus. O stosunku do chłopów pisali ks. Śmigielski w traktacie O lichwie i wyderkach. Inny jezuita, Jan Chądzyński, w Dyskursie kaptana jednego polskiego roku tysiąc sześćset pięćdziesiątego siódmego post Testum Transifigurationis Domini, w którym pokazuje, za co Bóg Koronę Polska karze i jako dalszego karania ujść mamy ${ }^{10}$ pisał wręcz, że nieszczęścia, które spotykają Rzeczpospolitą są wynikiem ucisku, jakiemu poddawani są chłopi. Tragiczny konflikt między szlachtą a królem z czasu Rokoszu Zebrzydowskiego był wynikiem sporu o zakres władzy króla i szlachty oraz próbą zwalczenia

8 Ks. J. Majakowski TJ, Matka Boża w dawnej Polsce ascezie, „Homo Dei” 26 (1957), s. $862-874$.

9 E. Reczek, Wstęp, s. 20-22 oraz Encyklopedia wiedzy..., s. 98 i s. 153.

10 Pisma polityczne z czasów panowania Jana Kazimierza Wazy, 1648-1668: publicystyka, eksorbitancje, projekty, memoriały, t. 1, oprac. S. Ochmann-Staniszewska, Wrocław 1989. 
rozrastającego się bezgranicznego poczucia wolności. Jezuici pragnęli przemodelować i uformować polskie społeczeństwo rozlicznymi sposobami. Wydaje się, że Pętko Panny Maryjej mogło być jednym z narzędzi.

\section{Struktura tekstu}

Pętko Panny Maryjej albo sposób oddawania się Błogosławionej Pannie Marii za sługę i niewolnika składa się z trzech części: teoretycznej, historycznej i praktycznej. W pierwszej autor wskazywał istotę niewolnictwa mariańskiego, w drugiej streszczał historię kultu, w ostatniej zaś przedstawiał modlitwy, jakie niewolnik mariański powinien odmawiać. O ile w drugiej i trzeciej części wątki filozoficzne wydają się drugorzędne w stosunku do warstwy religijno-historycznej, o tyle w części pierwszej można znaleźć wiele niezwykle istotnych dla filozofii aspektów.

W pierwszej części Pętka Panny Maryjej albo sposobów oddawania się Błogosławionej Pannie Marii za sługe i niewolnika można wyodrębnić kilka obszarów argumentacji, wyraźnie skierowanych do różnych odbiorców. Miało to, jak się zdaje, na celu maksymalne rozszerzenie grupy odbiorców dzieła, którymi byli zarówno przedstawiciele szlachty, jak i mieszczanie czy chłopi. Niewolnictwo mariańskie miało być projektem uniwersalnym, łączącym wszystkie stany w imię jednej idei.

Pętko Panny Maryjej rozpoczyna się od analizy filozoficzno-prawniczej, odwołującej się bezpośrednio do myśli scholastycznej. Należy podkreślić, że Autorzy zaczynają od prawniczego, a nie religijnego sposobu rozumowania. Idąc za ich wnioskowaniem, Maryja powinna być ogłaszana Panią wszystkich ludzi na mocy prawa dziedziczenia. Ponieważ, jak to zapisano w prawie, dzieci dziedziczą po rodzicach, a rodzice dziedziczą po dzieciach w przypadku ich przedwczesnej śmierci, i skoro Jezus Chrystus w swojej ludzkiej postaci był władcą ziemi i umarł jako człowiek, złożywszy wcześniej testament na krzyżu, gdzie powierzył świat w ręce swojej Matki, powinna ona dziedziczyć jego władzę. Nie odwołując się do myślenia religijnego, autor wskazuje, że prawo spadkowe (będące przecież dziedzictwem kultury przedchrześcijańskiej) ma zastosowanie. Pierwszy i kluczowy argument dowodzący zwierzchności Maryi nad ludźmi przytaczany jest nie ze względu na prawa religii, ale prawa logiki. Nie da się tutaj uniknąć odwołania do tradycji myśli scholastycznej, nakazującej logicznej analizy prawdy wiary.

Z części prawno-filozoficznej autor płynnie przechodzi do analizy, w której opiera się na autorytecie teologów. Udowadnia w niej, podpierając się my- 
śleniem religijnym, dlaczego Maryja powinna zostać uznana za władczynię świata i, co za tym idzie, dlaczego wszyscy ludzie powinni zostać jej niewolnikami. Chomontowski wskazuje na współuczestniczenie Maryi w męczeńskiej śmierci Jezusa. Jako pierwsza męczennica chrześcijańska dziedziczy również prawo do władania światem.

Trzecią grupą argumentacji, odwołującą się do znacznie prostszego odbiorcy, są opisy Maryi, jako wielkiej wojowniczki, co miało niewątpliwie wywołać najprostsze wyobrażenia. Maryja została przedstawiona jako „twierdza zbrojna w tysiące [...] tarczy”, która broni swoich niewolników. Wizja plastycznie i łatwo trafiająca do wyobraźni społeczeństwa silnie związanego z retoryką wojenną. Dopełnieniem tej narracji jest historia grzesznej kobiety, która zawdzięczała swoje zbawienie nabożeństwom ku czci Matki Boskiej, która były jej jedynym przejawem aktywności religijnej.

$\mathrm{Z}$ treści Pętka Panny Maryjej wyłania się spójny obraz świata, w którym kategoria sacrum odgrywa decydująca rolę. Staropolski świat polityki, nawet bez koncepcji niewolnictwa mariańskiego, był silnie nacechowany myśleniem religijnym. Rozdzielenie między strefą sacrum a strefą polityczności było umowne. Sejmy, sejmiki, wybór króla - wszystkie te uroczystości były ściśle związane z życiem religijnym. Msze święte zaczynały wydarzenia polityczne, w kościołach odbywały się obrady sejmików grodzkich. Pętko Panny Maryjej wpisywało się w obraz polityczności sarmackiej. Maryja na równi z Jezusem Chrystusem władała światem. Ludzie, bez względu na stan, mieli podporządkować się jej władzy i stać się niewolnikami. Pod terminem tym rozumiano bezwzględne poddaństwo i uniezależnienie swojej woli. Maryja włada nie tylko światem ziemskim, ale i światem duchowym. Pod jej panowaniem jest w równym stopniu niebo i piekło. Niewolnik Maryi jest nim również podczas głosowania na sejmie i kieruje się wskazówkami zawartymi w swojej duchowości.

Władza Maryi ustępuje jedynie Trójcy Świętej, przy czym w Pętku Panny Maryjej nie jest to wyraźnie zarysowane i trudno jednoznacznie oddzielić domenę Boga od domeny Maryi Panny. Jej władza rozciąga się również na władanie rzeczami świeckimi. Stąd też wskazuje się niekiedy Pętko Panny Maryjej jako jedno ze źródeł ślubów Jana Kazimierza, w których dokonał on intronizacji Maryi na Królową Polski ${ }^{11}$.

11 J. Pach, Rola Najświętszej Matki w duchowości europejskiej XVII w., [w:] Królowa Korony Polskiej. Od ślubów króla Jana Kazimierza do kardynała Stefana Wyszyńskiego, Jasna Góra Warszawa 2006, s. 91. Związki te, wbrew wykładni kościelnej, są dużo mniej oczywiste niż 


\section{Antysarmatyzm}

Pętko Panny Maryjej albo sposób oddawania się Błogosławionej Pannie Marii za stugę i niewolnika jest jednak w swojej wymowie przede wszystkim antysarmackie. W latach trzydziestych XVII istotną rolę odgrywało poczucie wolności szlacheckiej rozumianej jako niezależność od jakiegokolwiek zwierzchnictwa, w tym również i zwierzchnictwa władzy świeckiej. Rokosz Zebrzydowskiego w istotny sposób przemodelował sarmacką scenę polityczną i zachwiał pozycją króla.

Tymczasem w Pętku Panny Maryjej zaprezentowano model świata o silnym nacechowaniu mancypacyjnym, w którym wolny szlachcic miał uznawać siebie za niewolnika i bydlątko bez własnej woli, zależne od decyzji siły zwierzchniej. Zaproponowany przez jezuitów program miał złamać szlachecką złotą wolność, co więcej, zrównać w imię idei niewolnictwa mariańskiego wszystkie stany. Szlachcic zakuty w pęta, tak bowiem niektórzy zwolennicy tego nurtu manifestowali swój wybór, był antytezą dla bezgranicznej emancypacji i dążenia do poszerzania wolności. Przepisy zawarte na łamach Pętka Panny Maryjej miały na celu jak największe ograniczenie jego wolności osobistej, czyniąc z niego podległego sile wyższej, której wyrazicielem był przecież Kościół katolicki.

Echa tego można było wyczuć w ślubach maryjnych Jana Kazimierza, będących przecież nie tylko aktem religijnym, ale i aktem politycznym - podkreśleniem przynależności do krajów katolickich. Poświęcenie Polski w katedrze lwowskiej było również manifestacją zrzeczenia się wolności przez króla i osłabienie jego autorytetu na rzecz Matki Boga.

Niewolnictwo mariańskie zyskiwało coraz większą popularność, która znalazła wyraz w literaturze sarmackiej - szczególnie w tekstach Wespazjana Kochowskiego ${ }^{12}$, uznawanego za wyraziciela myśli epoki i sposobu, w jaki pojmowano wiarę. Niewolnictwo przerodziło się w gorący kult maryjny, do dziś obecny w Polsce.

Jednak najwyraźniejszym przejawem związku niewolnictwa mariańskiego i jego politycznym wydźwiękiem są złożone przez Jana Kazimierza w 1656 roku śluby lwowskie, w których król poddał Polskę pod ochronę Ma-

mogłoby się wydawać. Szerzej: P. Rzewuski, Pacta Conventa z Bogiem. Studium z teologii politycznej ślubów lwowskich, „Forum Artis Rhetoricae”, nr 1 (44), s. 26-27.

12 J. Nowak-Dłużewski, Wespazjan Kochowski jako pierwszy poeta kielecki, „Pamiętnik Kielecki”, Kielce 1947. 
ryi, w zamian za co zobowiązywał się otoczyć opieką chłopów znajdujących się w królewszczyznach ${ }^{13}$. Akt wskazywany jest, jako najważniejszy przejaw kultu maryjnego w historii Polski i zarazem punkt zwrotny w jej dziejach ${ }^{14}$. Odniesieniem dla przyszłej historii Polski, które miało swój epilog w wieku XX i ślubach kardynała Wyszyńskiego.

\section{Zasada edycji}

Podstawą dla niniejszej edycji Pętka Panny Maryjej albo sposobów oddawania się Błogosławionej Pannie Marii za sługe i niewolnika było wydanie księdza Edwarda Reczka ${ }^{15}$. W stosunku do pierwotnego tekstu uwspółcześniono zapis, zachowano jednak stare formy gramatyczne oraz oryginalną interpunkcję. Wskazówki bibliograficzne zapisane w okrągłych nawiasach są częścią oryginalnego tekstu. W nawiasach kwadratowych znajdują się wyjaśnienia dla nieużywanych już powszechnie terminów. Przypisy dolne oraz uwagi do tekstu zostały sporządzone przez księdza Reczka i są przytoczone za jego wydaniem tekstu.

\section{Bibliografia}

Encyklopedia wiedzy o jezuitach na ziemiach Polski i Litwy, 1564-1995, red. L. Grzebień i in., Wydział Filozoficzny Towarzystwa Jezusowego, Kraków 1996.

Górski K., Od religijności do mistyki, Lublin 1962.

${ }_{13}$ A że $z$ wielkim żalem serca mego uznaję, dla jęczenia w presji ubogiego pospólstwa oraczów, przez żolnierstwo uciemiężonego, od Boga mego sprawiedliwą karę przez siedem lat w królestwie moim różnymi plagami trapiąca nad wszystkich ponoszę, obowiązuje się, iż po uczynionym pokoju starać się będę ze stanami Rzeczypospolitej usilnie, ażeby odtąd utrapione pospólstwo wolne było od wszelkiego okrucieństwa, w czym, Matko Miłosierdzia, Królowo i Pani moja, jakoś mnie natchnęła do uczynienia tego wotum, abyś łaska miłosierdzia u Syna Twego uprosiła mi pomoc do wypetniania tego, co obiecuję. o. A. Kordecki, Nowa Gigantomachia, przeł. J. Łebkowski z r. 1858 [reprint], Częstochowa 1991, s. 128.

14 J. Pach, Rola Najświętszej Matki w duchowości europejskiej XVII w., [w:] Królowa Korony Polskiej. Od ślubów króla Jana Kazimierza do kardynała Stefana Wyszyńskiego, Jasna Góra-Warszawa 2006, s. 87.

15 E. Reczek, Niewolnictwo Mariańskie. Dwie Publikacje Polskich Jezuitów Z Roku 1632, oprac. E. Reczek, Rzym 1964, s. 100-160. 
Kordecki A. o., Nowa Gigantomachia, przeł. J. Łebkowski z r. 1858 [reprint], Częstochowa 1991.

Majakowski J., ks. TJ, Matka Boża w dawnej Polsce ascezie, „Homo Dei” 26 (1957), s. $862-874$.

Nowak-Dłużewski J., Wespazjan Kochowski jako pierwszy poeta kielecki, „Pamiętnik Kielecki”, Kielce 1947

Pach J., Rola Najświętszej Matki w duchowości europejskiej XVII w., [w:] Królowa Korony Polskiej. Od ślubów króla Jana Kazimierza do kardynała Stefana Wyszyńskiego, Jasna Góra - Warszawa 2006.

Pisma polityczne z czasów panowania Jana Kazimierza Wazy, 1648-1668: publicystyka, eksorbitancje, projekty, memoriaty, t. 1, opr. S. Ochmann-Staniszewska, Wrocław 1989.

Reczek E., Niewolnictwo Mariańskie. Dwie Publikacje Polskich Jezuitów Z Roku 1632, oprac. E. Reczek, Rzym 1964.

Rzewuski P., Pacta Conventa $z$ Bogiem. Studium z teologii politycznej ślubów lwowskich, „Forum Artis Rhetoricae”, nr 1 (44). 